\author{
Jacek Przygodzki \\ University of Wrocław, Poland \\ ORCID: 0000-0003-2459-933X \\ jacek.przygodzki@uwr.edu.pl
}

\title{
O administracji ogólnej II Rzeczypospolitej uwag kilka w świetle monografii Jarosława Kostrubca „Administracja ogólna w myśli prawniczej Drugiej Rzeczypospolitej"
}

\author{
Some Remarks on General Administration of the Second Polish \\ Republic in the Light of Jarosław Kostrubiec's Monograph \\ "Administracja ogólna w myśli prawniczej Drugiej Rzeczypospolitej"
}

\section{ABSTRAKT}

Niniejszy artykuł recenzyjny poświęcony jest problematyce administracji ogólnej Polski międzywojennej na kanwie monografii Jarosława Kostrubca pt. Administracja ogólna w myśli prawniczej Drugiej Rzeczypospolitej. Za główny cel Autor postawił sobie określenie pozycji ustrojowo-prawnej administracji ogólnej w polskiej myśli prawniczej opisywanego okresu, która znalazła wyraz nie tylko w literaturze, ale przede wszystkim w założeniach i projektach aktów normatywnych oraz w tezach funkcjonujących wtedy komisji dla usprawnienia administracji publicznej. Cel został osiągnięty, a czytelnik otrzymał klarowną monografię, przedstawiającą spojrzenie doktryny na ważne pojęcia prawa administracyjnego i nauki administracji: administrację ogólną, zespolenie administracji i dekoncentrację administracji. Niewątpliwym osiągnięciem Autora jest odnoszenie się do obecnie obowiązującej doktryny prawa administracyjnego przy analizie nomenklatury pojęciowej II Rzeczypospolitej. Pozwoliło to przybliżyć osiągnięcia polskie myśli polityczno-prawnej międzywojnia współczesnym.

Słowa kluczowe: II Rzeczpospolita; dekoncentracja administracji; zespolenie administracji; administracja ogólna; myśl prawnicza; komisje dla usprawnienia administracji publicznej; Jarosław Kostrubiec

CORRESPONDENCE ADDRESS: Jacek Przygodzki, PhD, dr. habil., Associate Professor, University of Wrocław, Faculty of Law, Administration and Economics, Uniwersytecka 22/26, 50-145 Wrocław, Poland. 
Administracja II Rzeczypospolitej to ciągle obszar zainteresowania historyków prawa czy badaczy doktryn politycznych i prawnych. To instytucja, którą tworzono w specyficznych warunkach i czasie. Po zakończeniu Wielkiej Wojny w $1918 \mathrm{r}$. odrodzone państwo polskie musiało stawić czoła konsekwencjom 123-letniej niewoli. W każdej dzielnicy powoli jednoczonej struktury była odmienna sytuacja gospodarcza, różna waluta, inny poziom oświaty, odrębny system ustawodawczy. Z wyjątkiem Małopolski, brakowało wystarczającej liczby odpowiednio przygotowanych obywateli naszego państwa do objęcia stanowisk w administracji. Do tego można dodać jeszcze jeden bardzo ważny fakt, mianowicie wielką różnorodność systemów administracyjnych odziedziczoną po państwach zaborczych. W północnej części dawnego Królestwa Polskiego, na obszarze niemieckiego Generalnego Gubernatorstwa Warszawskiego, była inna organizacja administracji, odrębna od części południowej, działającej w obrębie byłego austriacko-węgierskiego Generalnego Gubernatorstwa Lubelskiego. Ponadto na ziemiach byłego zaboru rosyjskiego, w zachodnich guberniach, istniały jeszcze pozostałości dawnego ustroju cesarstwa. W byłym zaborze pruskim funkcjonował w miarę jednolity ustrój administracyjny, a na ziemiach należących niegdyś do Austro-Węgier występowały różnice w systemie administracyjnym - pomijając już Spisz i Orawę, trzeba pamiętać, że ustawodawstwo sejmów krajowych, galicyjskiego i śląskiego, wprowadzało odmienne uregulowania. ${ }^{1}$

Obok postulatów wprowadzenia jednolitej i zunifikowanej administracji zaczęto chętniej dyskutować o budowaniu struktur w myśl nowych, światowych trendów organizacji i zarządzania zespołami ludzkimi pochodzącymi ze Stanów Zjednoczonych Ameryki Północnej. To właśnie ten kraj uważany jest za kolebkę nowoczesnych idei tworzenia nowej administracji, działającej sprawnie i oszczędnie, zatrudniającej odpowiednio wykształcony personel i korzystającej ze wzorów struktur biznesowych. Na gruncie europejskim podobne trendy pojawiły się w Wielkiej Brytanii, Belgii, Francji i Niemczech.

W piśmiennictwie historycznoprawym nie doczekaliśmy się całościowej monografii dotyczącej unifikacji administracji ogólnej II Rzeczypospolitej. Tematyka organizacji administracji poruszana była jednak w dziełach różnych badaczy. W okresie międzywojennym na plan pierwszy wysuwają się monografie Romana Hausnera, ${ }^{2}$ wybitnego urzędnika Ministerstwa Spraw Wewnętrznych, pracującego w resorcie od 1919 r., a także wybitnych profesorów prawa administracyjnego i państwowego: Kazimierza W. Kumanieckiego, Jerzego S. Langroda i Szczęsnego

1 K.W. Kumaniecki, Wzmocnienie państwa a administracja, „Gazeta Administracji i Policji Państwowej" 1924, nr 1, s. 2.

2 R. Hausner, Poczynania organizacyjno-oszczędnościowe w Polsce w latach 1918-1934, Warszawa 1935; idem, Zmiana Konstytucji a usprawnienie administracji, Warszawa 1931; idem, Pierwsze dwudziestolecie administracji spraw wewnętrznych, Warszawa 1939. 
Wachholza, ${ }^{3}$ Wacława Komarnickiego, ${ }^{4}$ Tadeusza Bigi ${ }^{5}$ i Władysława L. Jaworskiego. ${ }^{6}$ Współcześnie powyższą problematyką zajmowali się m.in.: piszący te słowa w monografii poświęconej komisjom dla usprawnienia administracji publicznej, ${ }^{7}$ Michał Gałędek, ${ }^{8}$ Hubert Izdebski i Michał Kulesza, ${ }^{9}$ Anna Tarnowska, ${ }^{10}$ Waldemar Kozyra, ${ }^{11}$ Jan Majchrowski, ${ }^{12}$ Adam Bosiacki ${ }^{13}$ i Halina Robótka. ${ }^{14}$

Obok wymienionych powyżej autorów pojawiła się również monografia Jarosława Kostrubca pt. Administracja ogólna w myśli prawniczej Drugiej Rzeczypospolitej. ${ }^{15}$ Autor jest pracownikiem Katedry Doktryn Polityczno-Prawnych i Prawa Rzymskiego Wydziału Prawa i Administracji Uniwersytetu Marii Curie-Skłodowskiej w Lublinie oraz jest uznanym badaczem idei państwa prawnego, doktrynalnych i dogmatycznych aspektów organizacji, funkcjonowania administracji publicznej, a także historii administracji i myśli administracyjnej.

W swojej monografii J. Kostrubiec za główny cel postawił sobie „określenie pozycji prawno-ustrojowo administracji ogólnej w polskiej myśli prawniczej dwudziestolecia międzywojennego, która znalazła wyraz nie tylko w literaturze, ale przede wszystkim w założeniach i projektach aktów normatywnych oraz tezach

${ }^{3}$ K.W. Kumaniecki, J.S. Langrod, S. Wachholz, Zarys ustroju, postępowania i prawa administracyjnego w Polsce, Kraków-Warszawa 1939.

${ }^{4}$ W. Komarnicki, Ustrój państwowy Polski wspótczesnej. Geneza i system, Wilno 1937.

5 T. Bigo, Zwiazki publicznoprawne w świetle ustawodawstwa polskiego, Warszawa 1928.

6 W.L. Jaworski, Nauka prawa administracyjnego. Zagadnienia ogólne, Warszawa 1924.

7 J. Przygodzki, Komisje dla usprawnienia administracji publicznej w II Rzeczypospolitej. Studium historycznoprawne, Wrocław 2019.

${ }^{8}$ M. Gałędek, Ustrój administracji ogólnej na Wileńszczyźnie w okresie międzywojennym, Gdańsk 2012; idem, Rozporządzenie Prezydenta RP z 19 stycznia 1928 r. o organizacji i zakresie działania władz administracji ogólnej - przełom $w$ budowie ustroju administracyjnego państwa polskiego doby międzywojennej, „Zeszyty Prawnicze” 2011, vol. 11(3).

${ }^{9}$ H. Izdebski, M. Kulesza, Administracja publiczna. Zagadnienia ogólne, Warszawa 1998.

${ }_{10}$ A. Tarnowska, Z dziejów unifikacji administracji II Rzeczypospolitej. Rola przepisów pruskich, Toruń 2012; idem, Niedostatki unifikacji administracji ogólnej. Doktryna i praktycy o koniecznych uzupetnieniach rozporządzenia Prezydenta RP z dnia 19 stycznia 1928 r., „Studia Iuridica Toruniensia” 2015, vol. 17.

${ }^{11}$ W. Kozyra, Polityka administracyjna ministrów spraw wewnętrznych Rzeczypospolitej Polskiej w latach 1918-1939, Lublin 2009; idem, Urząd wojewódzki w Lublinie w latach 1919-1939, Lublin 1999; idem, Kazimierz Młodzianowski - pierwszy piłsudczykowski minister spraw wewnętrznych Rzeczypospolitej Polskiej (15 V-2 X 1926 r.), „Studia z Dziejów Państwa i Prawa Polskiego” 2011, vol. 14.

12 J. Majchrowski, Ewolucja funkcji wojewody jako przedstawiciela Rzadu, Warszawa 2011.

13 A. Bosiacki, Od naturalizmu do etatyzmu. Doktryna samorzadu terytorialnego Drugiej Rzeczypospolitej 1918-1939, Warszawa 2006.

${ }^{14}$ H. Robótka, Kancelaria urzędów administracji państwowej II Rzeczypospolitej (procesy aktotwórcze), Torun 1993.

15 J. Kostrubiec, Administracja ogólna w myśli prawniczej Drugiej Rzeczypospolitej, Warszawa 2019. 
komisji dla usprawnienia administracji publicznej”. Autor podkreśla dalej we Wstępie, że ,[a]kty prawne czy ich projekty są dla mnie jedną z form egzemplifikacji określonych koncepcji i myśli ich twórców". ${ }^{16}$ Takie podejście należy ocenić jak najbardziej pozytywnie. Znając stan badań nad tematem badawczym, Autor postanowił w oparciu o „mediacyjny” model badawczy ${ }^{17}$ ukazać relacje pomiędzy ideą a sferą aktów normatywnych. Za H. Izdebskim podkreślił, że „to właśnie w aktach normatywnych dokonuje się inkorporacji treści doktrynalnych, albowiem regułą jest, że pierwotne są idee. W konsekwencji [...] trudno byłoby przeprowadzić »zdroworozsądkową analizę dogmatyczną« bez znajomości i zrozumienia »podłoża konceptualnego « całego systemu i jego instytucji”. ${ }^{18}$

Dla osiągnięcia swoich celów badawczych J. Kostrubiec przyjął ujęcie chronologiczne. Słusznie wyróżnił trzy linie rozwojowe w myśli prawniczej stanowiące o statusie administracji ogólnej II Rzeczypospolitej. Pierwszy okres w rozwoju myśli prawniczej związany był z potrzebą jak najszybszego zbudowania tymczasowych struktur admiracyjnych, wynikającą z różnic ustrojowych poszczególnych ziem zaborczych, a także z pracami nad przygotowaniem i uchwaleniem konstytucji. To właśnie ustawa zasadnicza uchwalona 17 marca $1921 \mathrm{r} .{ }^{19}$ opisywała kwestie administracji publicznej i podziału terytorialnego. Potwierdzała też system wprowadzony przez ustawodawstwo tymczasowe. Już w rozdziale drugim „Władza ustawodawcza” w art. 3 Konstytucja stwierdzała: „Rzeczpospolita Polska, opierając swój ustrój na zasadzie szerokiego samorządu terytorialnego, przekaże przedstawicielstwom tego samorządu właściwy zakres ustawodawstwa, zwłaszcza z dziedziny administracji, kultury gospodarstwa, który zostanie bliżej określony ustawami państwowymi” ${ }^{20} \mathrm{~W}$ rozdziale trzecim „Władza wykonawcza” w art. 65 stwierdzała, że do celów administracyjnych państwo polskie miało być podzielone na województwa, powiaty oraz gminy miejskie i wiejskie, które stanowiły również jednostki samorządu terytorialnego. Kolejny artykuł zapowiadał budowę struktur administracyjnych na zasadzie dekoncentracji. Organy administracji państwowej w poszczególnych jednostkach terytorialnych „miały w granicach określonych być zespolone w jednym urzędzie pod jednym zwierzchnictwem". Przewidywano również wprowadzenie zasady udziału obywatelskiego w działalności administracji w granicach określonych ustawami. Konstytucja przewidywała rozgraniczenie

16 Ibidem, s. 9.

17 O tej koncepcji zob. M. Maciejewski, T. Scheffler, O doktrynologii: rozważania dotyczace przedmiotu oraz metody doktryn politycznych i prawnych, [w:] Myślenie o polityce i prawie. Przedmiot - metoda-praktyka, red. I. Barwicka-Tylek, A. Czarnecka, M. Jaskólski, J. Malczewski, Warszawa 2015, s. 282-283.

18 J. Kostrubiec, op. cit., s. 11.

19 Ustawa z dnia 17 marca 1921 r. - Konstytucja Rzeczypospolitej Polskiej (Dz.U. 1921, nr 44, poz. 267), s. 633-658.

20 Ibidem. 
źródeł dochodów między państwem a samorządem w drodze ustawodawczej. Zapowiadała także wprowadzenie przepisów nadzorczych nad działalnością samorządu oraz odwołanie się od orzeczeń organów administracji rządowej i samorządowej do sądów administracyjnych, na czele z Najwyższym Trybunałem Administracyjnym. Ustawa zasadnicza przewidywała, obok samorządu terytorialnego, istnienie samorządu gospodarczego. ${ }^{21}$

Jako drugi okres tworzenia nowych koncepcji budowy administracji ogólnej J. Kostrubiec wskazał lata 1921-1928, czyli okres implementacji przepisów konstytucji marcowej do porządku prawnego. Skupił się głównie, zgodnie ze swoimi założeniami, na problemach z wdrożeniem jej art. 66, poświęconego zasadzie dekoncentracji i zespolenia w systemie administracji terytorialnej. Właśnie ten przepis budził największe kontrowersje wśród znawców prawa administracyjnego. Okres ten kończy wydanie rozporządzenia Prezydenta Rzeczypospolitej z dnia 19 stycznia 1928 r. o organizacji i zakresie działania władz administracji ogólnej. ${ }^{22}$ Rozporządzenie unifikacyjne po raz pierwszy w art. 2 pkt 2 wprowadziło legalną definicję administracji ogólnej, która brzmiała: „Wojewoda jest na obszarze województwa [...]. 2. Szefem administracji ogólnej, tj. administracji spraw wewnętrznych oraz innych działów administracji, bezpośrednio zespolonych we władzach administracji ogólnej", a na podstawie art. 118 - intensyfikację procesu dekoncentracji na rzecz władz administracji ogólnej. ${ }^{23}$

Trzeci okres określony przez J. Kostrubca obejmuje lata 1928-1933, czyli czasy działania ostatniej, piątej Komisji dla usprawnienia administracji publicznej pod formalnym przewodnictwem Kazimierza Bartla. Jednakże faktycznym jej szefem był Maurycy Z. Jaroszyński. Komisja postawiła sobie realizację bardzo ambitnego planu kompleksowej reorganizacji polskiej administracji. Miała zajmować się sprawami kształcenia urzędników, podziału administracyjnego, organizacji administracji centralnej, szerokiej dekoncentracji, procedur rachunkowo-kasowych, gospodarki materiałowej i systemu pracy w urzędach oraz przygotowaniem i ogłaszaniem obowiązujących przepisów. Komisja ta skupiła w swoim składzie

${ }^{21}$ Ibidem, s. 644-645; K. Kumaniecki, J. Langrod, L. Wachholz, op. cit., s. 17; W. Komarnicki, op. cit., s. 54-55; L. Górnicki, Prawo jako czynnik integracji państwa w latach II Rzeczypospolitej, „Acta Universitatis Wratislaviensis. Prawo” 2011, vol. 313, s. 122-123; M. Grzybowska, Decentralizacja i samorząd w II Rzeczypospolitej, Kraków 2003, s. 50; A. Bosiacki, op. cit., s. 35; R. Szwed, Samorzad terytorialny w Polsce w latach 1918-1939. Wybór materiałów źródtowych, Częstochowa 2000, s. 18; K. Kumaniecki, Centralizm i decentralizacja, [w:] Ankieta o konstytucji z 17 marca 1921, red. W. Jaworski, Warszawa 2014, s. 156; W. Wytrążek, Samorząd terytorialny w XX wieku w Polsce, Lublin 2009, s. 77; M. Kallas, Województwo w Drugiej Rzeczypospolitej: z dziejów podziałów terytorialnych w latach 1919-1939, „Acta Universitatis Nicolai Copernici. Nauki Humanistyczno-Społeczne. Historia" 1997, z. 30, s. 149-150; M.Z. Jaroszyński, Rozważania ideologiczne i programowe na temat samorzadu, Warszawa 1936, s. 6-10.

${ }^{22}$ Dz.U. 1928, nr 11, poz. 86.

${ }^{23}$ Ibidem. 
polityków, ale - co ważne - miała również prawo powoływania do swojego składu, jako ekspertów, znawców przedmiotu i z takiego prawa często korzystała. Jest symptomatyczne, że w swoich pracach brała też pod uwagę wnioski płynące z podróży studyjnych po krajach Europy, kiedy to eksperci Komisji mogli zaznajomić się z tamtejszymi rozwiązaniami prawnymi. ${ }^{24}$

Powyższy podział pozwolił J. Kostrubcowi na stratyfikację monografii na cztery rozdziały. W mojej ocenie pierwszy rozdział Administracja ogólna w ujęciu doktrynalnym i normatywnym jest kluczową częścią książki, w której Autor dokładnie przedstawił najważniejsze pojęcia dla całości wywodów: administracji ogólnej, zespolenia i dekoncentracji administracji. Zostały one przeanalizowane w oparciu o poglądy najważniejszych przedstawicieli nauki i praktyki, mających ogromny wpływ na polską myśl prawniczą i porządek prawny II Rzeczypospolitej. Przeczytamy tutaj właściwie zestawione poglądy Kazimierza W. Kumanieckiego, Władysława L. Jaworskiego, Wacława Komarnickiego, Tadeusza Hilarowicza, Stanisława Kasznicy, Jerzego Panejki, Tadeusza Bigi, Romana Hausnera, Ignacego Czumy czy Władysława Czapińskiego. Klarowność wywodów Autora powoduje, że niewątpliwie każdy, kto będzie badał polską administrację międzywojenną, sięgnie do tych ustaleń. ${ }^{25}$

Drugi rozdział recenzowanej monografii poświęcony jest pracom nad stworzeniem systemu administracyjnego odrodzonego państwa polskiego. Państwo polskie musiało podjąć się od pierwszych chwil po odzyskaniu niepodległości funkcji integracji życia społecznego, a spoiwami były tożsamość narodowa, wspólna kultura duchowa i materialna oraz historia. Rzeczpospolita, jak pisał Konstanty Grzybowski, była państwem narodu polskiego, a suwerenem był naród polski, czyli wszyscy obywatele na równi. Należało zatem przezwyciężyć tendencje odśrodkowe, dokonując integracji, a więc połączenia części w całość, zespolenia i zharmonizowania elementów zbiorowości społecznej. ${ }^{26}$ Ważnym elementem takiej polityki było zbudowanie zrębów jednolitej administracji. J. Kostrubiec w swojej pracy opisał projekty Jaworskiego ${ }^{27}$ oraz Polskiego Towarzystwa Prawniczego we Lwowie, które w porozumieniu ze środowiskami prawniczymi Krakowa, Poznania i Warszawy powołało sekcję administracyjną dla ,pielęgnowania nauk administracyjnych, a przede wszystkim w chwili obecnej - współpracy nad reformą władz administracyjnych w Polsce". ${ }^{28}$ Dalej przedstawiono koncepcję Edwarda Duba-

${ }^{24}$ J. Przygodzki, Komisje dla usprawnienia administracji..., s. 159.

25 J. Kostrubiec, op. cit., s. 23-87.

${ }^{26}$ L. Górnicki, op. cit., s. 112; K. Grzybowski, Rola prawa w likwidacji podziałów zaborczych oraz integracji państwa polskiego, [w:] Droga przez pótwiecze. O Polsce lat 1918-1968, Warszawa 1969, s. 63-64.

27 W.L. Jaworski, Zarys urządzenia administracji w Polsce, Kraków 1918.

${ }^{28}$ Projekt organizacji władz administracyjnych $w$ Polsce, opracowany przez Sekcje administracyjna Towarzystwa prawniczego we Lwowie, „Przegląd Prawa i Administracji” 1919, z. 4-6, s. 182; 
nowicza zawartą w dziele Sprawa politycznej administracji w Polsce oraz projekt rządu Królestwa Polskiego Jana Kantego Steczkowskiego. ${ }^{29}$ Rozdział wieńczą informacje o pracach nad ustawą zasadniczą. Autor monografii dokładnie przenalizował rozwiązania dotyczące administracji we wszystkich projektach konstytucji. ${ }^{30}$

W tej części książki w mojej ocenie zabrakło dokładniejszej informacji o powołaniu pierwszej komisji dla usprawnienia administracji publicznej. To właśnie rząd Leopolda Skulskiego ${ }^{31}$ zaczął przygotowywać się do podjęcia reformy administracji. Na posiedzeniu Rady Ministrów 16 stycznia 1920 r. podjęto decyzję o powołaniu, w porozumieniu z Prezydium Rady Ministrów i Ministerstwem Skarbu, specjalnego organu urzędowego, którego celem miało być dokonanie kontroli nad uproszczeniem administracji, należytym wykorzystaniem potencjału urzędników oraz zmniejszeniem ich liczby. ${ }^{32}$ Ostatecznie realizacją powyższego zamierzenia rządu Skulskiego zajął się pierwszy rząd Wincentego Witosa. ${ }^{33}$ Dnia 29 lipca 1920 r. „rozporządzeniem Prezydenta Ministrów w przedmiocie Komisji dla spraw oszczędności państwowych" określono jej skład i zadania. Komisję miały tworzyć trzy osoby: Stanisław Wojciechowski, były minister spraw wewnętrznych w rządzie Ignacego Jana Paderewskiego i Leopolda Skulskiego, delegowany przez Prezydium Rady Ministrów, Jan Żarnowski jako osoba wyznaczona z Ministerstwa Skarbu oraz Ludomir Grendyszyński, naczelnik Wydziału Organizacyjnego Prezydium Rady Ministrów. Głównym zadaniem Komisji miało być „opracowanie reformy administracji państwowej w celu jej uproszczenia, redukcji nadmiernej ilości urzędów i personelu oraz zapewnienie jednolitości i sprawności działania urzędów we wszystkich instancjach"34. Przedmiotem działania miały być również przedsiębiorstwa państwowe w celu polepszenia ich sytuacji finansowej. Komisja otrzymała prawo badania ustroju i czynności wszystkich urzędów, mogła wzywać na swoje posiedzenia urzędników ministerstw i urzędów centralnych do szefów sekcji włącznie oraz powoływać ekspertów. Rozporządzenie zobowiązywało terenowe ekspozytury ministerstw i urzędów centralnych do dostarczania przez miejscowych wojewodów i starostów żądanych przez Komisję informacji o stanie zatrudnienia, uposażeniach oraz zakresie obowiązków urzędników. ${ }^{35}$ Jak widać,

J. Przygodzki, Koncepcje podziału terytorialnego Rzeczypospolitej Polskiej w latach 1918-1921, [w:] Na szlakach niepodległej. Polska myśl polityczna w latach 1918-1939, red. M. Marszał, M. Sadowski, Wrocław 2009, s. 291-301.

29 J. Kostrubiec, op. cit., s. 117-137.

${ }^{30}$ Ibidem, s. 138-167.

31 A. Wątor, Gabinet Leopolda Skulskiego13.XII.1919-19.VI.1920, [w:] Gabinety Drugiej Rzeczpospolitej, red. J. Faryś, J. Pajewski, Szczecin-Poznań 1991, s. 55-61.

${ }^{32}$ Monitor Polski 1920 (16 stycznia), nr 16.

33 A. Wątor, Gabinet Wincentego Witosa 24.VII.1920-13.IX.1921, [w:] Gabinety..., s. 69-78.

${ }^{34}$ Monitor Polski 1920 (20 sierpnia), nr 188.

35 Ibidem; R. Hausner, Poczynania organizacyjno-oszczędnościowe ..., s. 44-45; idem, Dekoncentracja, „Gazeta Administracji i Policji Państwowej” 1929, nr 1, s. 2 (2). Na temat komisji zob. 
zakres prac powyższej Komisji wprawdzie nie zawierał wprost zadań dotyczących dekoncentracji i zespolenia, czyli kwestii interesujących J. Kostrubca w monografii, można było jednak poświęcić temu organowi więcej miejsca.

Okresowi 1921-1928 poświęcony jest trzeci rozdział książki. Art. 66 konstytucji marcowej dał asumpt do dyskusji wybitnych administratywistów i praktyków nad koncepcją zespolenia i dekoncentracji administracji. To właśnie w tym periodzie działały trzy komisje dla usprawnienia administracji: Komisja dla Reformy Administracji pod formalnym przewodnictwem premiera Władysława Sikorskiego, Komisja Trzech z 1926 r. i powołana w tym samym roku Komisja dla Reorganizacji Administracji pod przewodnictwem ministra spraw wewnętrznych Kazimierza Młodzianowskiego. W mojej ocenie należałoby poświęcić trochę więcej miejsca tej ostatniej, ponieważ jednym z jej głównych zadań było przygotowanie projektu organizacji i funkcjonowania ministerstw. Już na drugim posiedzeniu, które odbyło się 6 lipca 1926 r., przedstawiła ona tezy przyszłych prac. Komisja wskazywała, że podstawą jej działania, określającego kompetencje ministerstw, powinna być jak najdalej posunięta dekoncentracja władzy. Do właściwych zadań ministerstwa powinny należeć: zasadnicza organizacja aparatu centralnego i lokalnego z pozostawieniem pewnej swobody władzom miejscowym; nadzór nad pracami urzędów podległych ministerstwu; wydawanie decyzji w toku instancji i w drodze nadzoru z jak najdalej idącym zastosowaniem konstytucyjnej zasady dwuinstancyjności; ustalenie ogólnych zasad polityki ministerstwa i udzielanie dyrektyw administracji lokalnej; działalność legislacyjna. ${ }^{36}$

W rozdziale trzecim znalazł się również podrozdział poświęcony projektowi zgłoszonemu w Sejmie przez posła Polskiego Stronnictwa Ludowego „Piast” Alfonsa Erdmana pt. „Ustawa Zasadnicza o ustroju władz administracyjnych”. Składał się on z 21 artykułów podzielonych na cztery rozdziały: Rozdział I. „O Podziale administracyjnym”, Rozdział II. „O zasadach ustroju administracyjnego”, Rozdział III. „O zasadach ustroju terytorialnego”, Rozdział IV. „Przepisy końcowe”. Według wniosku obszar województwa planowano na 20 tys. km² o liczbie ludności 1,5 mln mieszkańców. Powiaty liczyłyby od 30 tys. do 60 tys. mieszkańców na obszarze od $750 \mathrm{~km}^{2}$ do $1000 \mathrm{~km}^{2}$ w województwach wschodnich. Warszawa miała być odrębnym województwem, a miasta powyżej 25 tys. mieszkańców stanowiłyby odrębne powiaty. We wniosku proponowano skasowanie komisariatów obwodowych w województwie poznańskim i urzędów rejonowych w województwach

J. Przygodzki, Kilka uwag o Komisji dla spraw oszczędności państwowych z 1920 r., [w:] Studia historycznoprawne. Tom dedykowany Profesorowi Alfredowi Koniecznemu (w osiemdziesiata rocznice urodzin), red. T. Kruszewski, J. Przygodzki, Wrocław 2014, s. 177-186; idem, Komisje dla usprawnienia administracji..., s. 61-62.

${ }^{36}$ Archiwum Akt Nowych w Warszawie, zespół Ministerstwo Spraw Wewnętrznych, sygn. 1, s. 28. 
wschodnich. Posłowie proponowali skasowanie obszarów dworskich i wprowadzenie gmin jednowioskowych. Wszystkie okręgi administracji specjalnej miały być uzgodnione z podziałem administracyjnym państwa. ${ }^{37}$

W tej części można byłoby wspomnieć o pierwszym wniosku reformującym system podziału administracyjnego państwa pn. „Wniosek nagły posła A. Erdmana i tow. z Klubu P.S.L. w sprawie nowego podziału administracyjnego Rzeczypospolitej Polskiej”. Złożony został w Sejmie Ustawodawczym 29 lipca 1921 r. Erdman i trzydziestu posłów klubu parlamentarnego PSL „Piast” dokonali w nim oceny ówczesnego podziału państwa i podali projekt nowego kształtu Rzeczypospolitej. ${ }^{38}$ Umieszczenie tego wniosku uzupełniłoby ustalenia dotyczące poglądów na podział administracyjny państwa.

Ostatni rozdział monografii poświęcony jest pracom ostatniej komisji powołanej przez rząd premiera Kazimierza Bartla uchwałą Rady Ministrów z dnia 27 września 1928 r. - Komisji dla Usprawnienia Administracji Publicznej. Do jej zadań miało należeć opracowanie planu usprawnienia administracji publicznej, zarówno pod względem organizacyjnym, jak i zakresu działania, w dziedzinie metod prac w urzędach, systemu kształcenia personelu urzędniczego oraz całej polityki personalnej. Komisja miała się składać z osób powołanych przez premiera, które dla realizacji jej zadań miały prawo przeprowadzania niezbędnych badań w poszczególnych urzędach w sposób niehamujący toku spraw urzędowych. ${ }^{39}$

Autor nie opisał całości prac powyższego gremium. Skupił się, zgodnie z nakreślonym celem książki, na kwestii organizacji administracji ogólnej w świetle projektu R. Hausnera, dekoncentracji, podziału administracyjnego państwa dla celów administracji ogólnej oraz ustroju województwa stołecznego i miasta stołecznego Warszawy. Pozostałych zadań komisji, np. spraw urzędniczych, organizacji kontroli administracji publicznych czy systemów biurowości, w monografii nie uwzględniono. Jak jednak Autor słusznie we Wstępie jasno skonstatował: „Na gruncie niniejszej monografii przyjąłem bowiem założenie, że przedmiot badań nad administracją ogólną w ujęciu doktrynalnym, ze względu na rozległość problematyki, musi zostać ograniczony do rozważań służących jedynie określeniu jej pozycji prawno-ustrojowej na kanwie myśli prawniczej". ${ }^{40}$

Podsumowując, należy stwierdzić, że mimo kilku wątków dyskusyjnych, monografia Jarosława Kostrubca to dzieło wartościowe, spójne, odpowiadające na postawione przez Autora pytania badawcze. Czytelnik otrzymał klarowną mono-

${ }_{37}$ Dekret o organizacji administracji rzadowej, „Gazeta Administracji” 1936, nr 17, s. 559-560.

38 Odpis wniosku A. Erdmana w: J. Hubert, Sprawa nowego podziału Rzeczypospolitej Polskiej na województwa. Uwagi nad wnioskiem nagłym posła Erdmana i tow. z klubu P.S.L. (Druk sejmowy Nr 2963), Poznań 1921, s. 24-25; J.S. Langrod, Ze studiów nad podziatem administracyjnym państwa, Kraków 1931, s. 117-118.

${ }^{39}$ Monitor Polski 1928, nr 224.

${ }^{40}$ J. Kostrubiec, op. cit., s. 22. 
grafię, przedstawiającą spojrzenie doktryny na ważne pojęcia prawa administracyjnego i nauki administracji: administrację ogólną, zespolenie i dekoncentrację administracji. Ustalenia Autora uzupełniają pewną lukę w historii państwa i prawa oraz historii administracji.

Osobno należy zauważyć, że niewątpliwym osiągnięciem Autora jest odnoszenie się do obecnie obowiązującej doktryny prawa administracyjnego przy analizie nomenklatury pojęciowej II Rzeczypospolitej. Pozwoliło to przybliżyć osiągnięcia polskiej myśli polityczno-prawnej międzywojnia współczesnym badaczom.

Na koniec należy stwierdzić, że Autor swoimi ustaleniami podkreślił wysoką pozycję lubelskiego ośrodka historyków państwa i prawa w badaniach nad administracją publiczną reprezentowanych również przez Profesorów Wojciecha Witkowskiego i Grzegorza Smyka.

\section{BIBLIOGRAFIA}

\section{Archiwalia}

Archiwum Akt Nowych w Warszawie, zespół Ministerstwo Spraw Wewnętrznych, sygn. 1.

\section{Literatura}

Bigo T., Związki publicznoprawne w świetle ustawodawstwa polskiego, Warszawa 1928.

Bosiacki A., Od naturalizmu do etatyzmu. Doktryna samorzadu terytorialnego Drugiej Rzeczypospolitej 1918-1939, Warszawa 2006.

Dekret o organizacji administracji rzadowej, „Gazeta Administracji” 1936, nr 17.

Gałędek M., Rozporzadzenie Prezydenta RP z 19 stycznia 1928 r. o organizacji i zakresie działania władz administracji ogólnej - przełom w budowie ustroju administracyjnego państwa polskiego doby międzywojennej, „Zeszyty Prawnicze” 2011, vol. 11(3),

DOI: https://doi.org/10.21697/zp.2011.11.3.06.

Gałędek M., Ustrój administracji ogólnej na Wileńszczyźnie w okresie międzywojennym, Gdańsk 2012.

Górnicki L., Prawo jako czynnik integracji państwa w latach II Rzeczypospolitej, „Acta Universitatis Wratislaviensis. Prawo" 2011, vol. 313.

Grzybowska M., Decentralizacja i samorząd w II Rzeczypospolitej, Kraków 2003.

Grzybowski K., Rola prawa w likwidacji podziałów zaborczych oraz integracji państwa polskiego, [w:] Droga przez pótwiecze. O Polsce lat 1918-1968, Warszawa 1969.

Hausner R., Dekoncentracja, „Gazeta Administracji i Policji Państwowej” 1929, nr 1.

Hausner R., Pierwsze dwudziestolecie administracji spraw wewnętrznych, Warszawa 1939.

Hausner R., Poczynania organizacyjno-oszczędnościowe w Polsce w latach 1918-1934, Warszawa 1935.

Hausner R., Zmiana Konstytucji a usprawnienie administracji, Warszawa 1931.

Hubert J., Sprawa nowego podziału Rzeczypospolitej Polskiej na województwa. Uwagi nad wnioskiem nagtym posta Erdmana i tow. z klubu P.S.L. (Druk sejmowy Nr 2963), Poznań 1921.

Izdebski H., Kulesza M., Administracja publiczna. Zagadnienia ogólne, Warszawa 1998.

Jaroszyński M.Z., Rozważania ideologiczne i programowe na temat samorzadu, Warszawa 1936. 
Jaworski W.L., Nauka prawa administracyjnego. Zagadnienia ogólne, Warszawa 1924.

Jaworski W.L., Zarys urządzenia administracji w Polsce, Kraków 1918.

Kallas M., Województwo w Drugiej Rzeczypospolitej: z dziejów podziałów terytorialnych w latach 1919-1939, „Acta Universitatis Nicolai Copernici. Nauki Humanistyczno-Społeczne. Historia” 1997, z. 30.

Komarnicki W., Ustrój państwowy Polski współczesnej. Geneza i system, Wilno 1937.

Kostrubiec J., Administracja ogólna w myśli prawniczej Drugiej Rzeczypospolitej, Warszawa 2019.

Kozyra W., Kazimierz Młodzianowski - pierwszy piłsudczykowski minister spraw wewnętrznych Rzeczypospolitej Polskiej (15 V-2 X 1926 r.), „Studia z Dziejów Państwa i Prawa Polskiego” 2011, vol. 14.

Kozyra W., Polityka administracyjna ministrów spraw wewnętrznych Rzeczypospolitej Polskiej w latach 1918-1939, Lublin 2009.

Kozyra W., Urząd wojewódzki w Lublinie w latach 1919-1939, Lublin 1999.

Kumaniecki K., Centralizm i decentralizacja, [w:] Ankieta o konstytucji z 17 marca 1921, red. W. Jaworski, Warszawa 2014.

Kumaniecki K.W., Wzmocnienie państwa a administracja, „Gazeta Administracji i Policji Państwowej” $1924, \mathrm{nr} 1$.

Kumaniecki K.W., Langrod J.S., Wachholz S., Zarys ustroju, postepowania i prawa administracyjnego w Polsce, Kraków-Warszawa 1939.

Langrod J.S., Ze studiów nad podziałem administracyjnym państwa, Kraków 1931.

Maciejewski M., Scheffler T., O doktrynologii: rozważania dotyczace przedmiotu oraz metody doktryn politycznych i prawnych, [w:] Myślenie o polityce i prawie. Przedmiot-metoda-praktyka, red.

I. Barwicka-Tylek, A. Czarnecka, M. Jaskólski, J. Malczewski, Warszawa 2015.

Majchrowski J., Ewolucja funkcji wojewody jako przedstawiciela Rządu, Warszawa 2011.

Projekt organizacji władz administracyjnych w Polsce, opracowany przez Sekcje administracyjna Towarzystwa prawniczego we Lwowie, „Przegląd Prawa i Administracji” 1919, z. 4-6.

Przygodzki J., Kilka uwag o Komisji dla spraw oszczędności państwowych z 1920 r., [w:] Studia historycznoprawne. Tom dedykowany Profesorowi Alfredowi Koniecznemu (w osiemdziesiata rocznice urodzin), red. T. Kruszewski, J. Przygodzki, Wrocław 2014.

Przygodzki J., Komisje dla usprawnienia administracji publicznej w II Rzeczypospolitej. Studium historycznoprawne, Wrocław 2019.

Przygodzki J., Koncepcje podzialu terytorialnego Rzeczypospolitej Polskiej w latach 1918-1921, [w:] Na szlakach niepodległej. Polska myśl polityczna w latach 1918-1939, red. M. Marszał, M. Sadowski, Wrocław 2009.

Robótka H., Kancelaria urzędów administracji państwowej II Rzeczypospolitej (procesyaktotwórcze), Torun 1993.

Szwed R., Samorzad terytorialny w Polsce w latach 1918-1939. Wybór materiatów źródtowych, Częstochowa 2000.

Tarnowska A., Niedostatki unifikacji administracji ogólnej. Doktryna i praktycy o koniecznych uzupetnieniach rozporządzenia Prezydenta RP z dnia 19 stycznia 1928 r., „Studia Iuridica Toruniensia" 2015, vol. 17, DOI: https://doi.org/10.12775/SIT.2015.028.

Tarnowska A., Z dziejów unifikacji administracji II Rzeczypospolitej. Rola przepisów pruskich, Torun 2012.

Wątor A., Gabinet Leopolda Skulskiego13.XII.1919-19.VI.1920, [w:] Gabinety Drugiej Rzeczpospolitej, red. J. Faryś, J. Pajewski, Szczecin-Poznań 1991.

Wątor A., Gabinet Wincentego Witosa 24.VII.1920-13.IX.1921, [w:] Gabinety Drugiej Rzeczpospolitej, red. J. Faryś, J. Pajewski, Szczecin-Poznań 1991.

Wytrążek W., Samorząd terytorialny w XX wieku w Polsce, Lublin 2009. 


\begin{abstract}
Akty prawne
Monitor Polski 1920 (16 stycznia), nr 16.

Monitor Polski 1920 (20 sierpnia), nr 188.

Monitor Polski 1928, nr 224.

Ustawa z dnia 17 marca 1921 r. - Konstytucja Rzeczypospolitej Polskiej (Dz.U. 1921, nr 44, poz. 267).

Rozporządzenie Prezydenta Rzeczypospolitej z dnia 19 stycznia 1928 r. o organizacji i zakresie działania władz administracji ogólnej (Dz.U. 1928, nr 11, poz. 86).
\end{abstract}

\begin{abstract}
This review article is devoted to the problems of general administration in interwar Poland, based on Jarosław Kostrubiec's monograph entitled Administracja ogólna w myśli prawniczej Drugiej Rzeczypospolitej. The Author's main goal was to determine the political and legal position of general administration in Polish jurisprudence of the discussed period, which found expression not only in the literature of the subject, but first and foremost in the premises and drafts of normative acts, as well as the propositions of then functioning Commissions for the Improvement of Public Administration. This objective has been achieved, and the reader has been presented with a concise monograph, which presents the doctrine's view of the important concepts of administrative law and the science of administration: general administration, consolidation of administration, and deconcentration of administration. The unquestionable achievement of the Author is his references to the currently binding doctrine of administrative law when analyzing the conceptual nomenclature of the Second Polish Republic. This has allowed to bring the achievements of Polish jurisprudence of the interwar period closer to his contemporaries.
\end{abstract}

Keywords: the Second Polish Republic; deconcentration of administration; consolidation of administration; general administration; jurisprudence; Commissions for the Improvement of Public Administration; Jarosław Kostrubiec 